\title{
Review of genomics of Barrett's esophagus and esophageal adenocarcinoma
}

\author{
Khaled Assim Karkout ${ }^{1 *}$, Amgad El Sherif ${ }^{2}$, Mohammed Yaman ${ }^{3}$, Dongfeng Tan ${ }^{4}$ and Sadir Al Rawi ${ }^{1}$ \\ ${ }^{1}$ B1Department of General Surgery, Division of Surgical Oncology, Tawam Hospital, Al Ain, UAE \\ ${ }^{2}$ Department of General Surgery, Division of Thoracic Surgery, Tawam Hospital, Al Ain, UAE \\ ${ }^{3}$ Department of General Surgery, Division of Thoracic Surgery, Al Mafraq Hospital, Abu Dhabi, UAE \\ ${ }^{4}$ Department of Pathology, The University of Texas MD Anderson Cancer Center, Houston, Texas, USA
}

\begin{abstract}
In Barrett's esophagus, esophageal epithelium is replaced by intestinal type columnar epithelium. Esophagogastroduodenoscopy, endoscopic ultrasonography and biopsy are advanced diagnostic tools for Barrett's esophagus. Histological corroboration of endoscopically visible columnarisation results in highest diagnostic accuracy. Surveillance endoscopy with an intensive biopsy every 3 months is recommended after dysplasia is identified. Endoscopic ablation is the first line therapy in that case. Ablation can result in squamous re-epithelialization although rests of glandular metaplasia may remain beneath the neo-squamous epithelium Thus ablation remains experimental until further prospective randomized studies. Surgical resection alleviates the symptoms of acidic reflux but does not decrease the risk of progression from Barrett's esophagus to esophageal adenocarcinoma. Protein pump inhibitors have been linked to a decreased risk of developing esophageal adenocarcinoma, if they are used for more than 2 to 3 years. However, it is unknown whether they can inhibit progression from Barrett's esophagus to esophageal adenocarcinoma. Linkage between proton pump inhibitors and the genomics of the Barrett's esophagus and esophageal adenocarcinoma is still unclear yet. Studies have focused on the risks of the long term suppression of gastric acidity in the prevention and treatment of Barrett's esophagus. However, only few studies are available regarding genomics of this condition. In this review we discuss the genomics of Barrett's esophagus and esophageal adenocarcinoma. We try here to collect the most recent data on this topic and make it readily available for researchers and reviewers.
\end{abstract}

\section{Introduction}

Barrett's esophagus is defined as metaplasia in the distal esophageal cells; in which normal stratified squamous epithelium is replaced by intestinal type columnar epithelium as an adaptation to the acidic environment of gastric reflux. it can be classified as long segment or short segment. Short segment disease is less than three centimeters in length, and has short symptoms duration, in addition, patients with short segment disease have normal lower esophageal sphincter pressure and experience only upright reflux on a 24 hour $\mathrm{pH}$ test. Long segment disease is more than three centimeters in length and has longer symptoms duration. Barrett's esophagus is associated with erosions and ulceration of the normal mucosa [1-5]. This condition is most commonly diagnosed in white males in their 50s with a history of gastroesophageal reflux, pyrosis, acid regurgitation, and sometimes dysphagia. Histological corroboration of endoscopically visible columnarisation results in highest diagnostic accuracy [6].

Barrett's esophagus is present in $1 \%$ to $2 \%$ of the general population but up to $14 \%$ of patients with gastric reflux. It is associated with a 30 - to 125-fold increased risk of esophageal adenocarcinoma (EAC) as a result of metaplasia, and low and high grade dysplasia [7]. Once dysplasia is identified, endoscopic ablation is a choice for treatment. Ablation can result in squamous re-epithelialization although rests of glandular metaplasia may remain beneath the neo-squamous epithelium in up to $60 \%$ of patients. The significance of these rests is unknown as is the optimal ablative technique, Thus ablation remains experimental until further prospective randomized studies [6]. On the other hand, surgical resection alleviates symptoms from acidic reflux but doesn't decrease the risk of progression from Barrett's esophagus to EAC. EAC is an aggressive tumor with a poor prognosis, it is diagnosed most commonly in white men in their 50s, there is often metastasis at diagnosis $[8,9]$, and the 5 year survival rate is $13.4 \%$ while the 10 year survival rate is $10.2 \%[10,11]$. As per the National Cancer Institute the overall 5-year survival rate in the Surveillance, Epidemiology, and end results database is $16.8 \%$ [12]. EAC is the eighth most common and the sixth most lethal cancer in the world [13]. In the United States, an estimated 16,470 new cases and 14,530 deaths from this disease were expected in 2009 [14]. The disease's genomic background has been established for many cancers. Barrett's esophagus can be easily visualized and biopsied using endoscopy, the technique makes it easy to monitor this premalignant state and perform endoscopic surveillance, and genomic studies $[15,16]$. Evidence shows that loss of heterozygosity (LOH, which was used recently to demonstrate that premalignant lesions situated around the tumor consist of different clonal lineages), methylation and mutations that lead to the inactivation of CDKN2A, are early events that lead to clonal expansion in the Barrett's esophagus tissue [17-19]. In the absence of CDKN2A, inactivation of TP53 by mutation and $\mathrm{LOH}$

Correspondence to: Khaled Karkout, Department of General Surgery, Division of Surgical Oncology, Tawam hospital Al Ain, United Arab Emirates; E-mail: dr.khalood@hotmail.com

Key words: Barrett's esophagus, oncogenes, genomic, gastroesophageal reflux, esophageal adenocarcinoma

Received: February 10, 2015; Accepted: February 16, 2015; Published: February 18,2015 
Table 1. Summary of genomic findings of Barrett's esophagus.

\begin{tabular}{|c|c|c|c|}
\hline & \multicolumn{3}{|c|}{ Chromosome } \\
\hline Mutations\Oncogene & Gain & Loss & Rearrangement \\
\hline TP53 & $1 \mathrm{q}$ & $4 \mathrm{pq}$ & $1 \mathrm{p}$ \\
\hline APC3 & $3 \mathrm{q}$ & $5 \mathrm{q}$ & $3 \mathrm{q}$ \\
\hline CDKN2A & $5 \mathrm{p}$ & $9 \mathrm{p}$ & $11 \mathrm{p}$ \\
\hline MCC & $6 \mathrm{p}$ & $14 \mathrm{q}$ & $22 \mathrm{q}$ \\
\hline retinoblastoma 1 & $7 \mathrm{pq}$ & $16 \mathrm{q}$ & \\
\hline DCC & $8 \mathrm{q}$ & $17 \mathrm{p}$ & \\
\hline NO MUTATION IN DPC4 & 11 & $18 \mathrm{q}$ & \\
\hline ERBB2 & $12 \mathrm{q}$ & 21 & \\
\hline EGFR & $13 \mathrm{q}$ & $\mathrm{Y}$ & \\
\hline SRC & 14 & & \\
\hline & $15 \mathrm{q}$ & & \\
\hline Histidine & $17 \mathrm{q}$ & & \\
& $18 \mathrm{p}$ & & \\
\hline & $20 \mathrm{q}$ & & \\
\hline & $\mathrm{Xpq}$ & & \\
\hline
\end{tabular}

is subsequently linked to progression, from increased $4 \mathrm{~N}$ fractions (G2/tetraploidy), to aneuploidy and EAC [20]. A cytogenic analysis of Barrett's esophagus showed losses of chromosomes 4, 18, 21 and $Y$, and gains of 14 and 20. Nevertheless rearrangements were seen on 1p, 3q, $11 p$, and 22q [21]. For adenocarcinomas around the gastroesophageal junction in situ hybridization analyses using chromosome-specific centromeric probes showed gains of chromosomes $6,7,8,11$, and 12 and losses of 17 and $\mathrm{Y}$ [22]. Losses were commonly seen on 4pq, $5 q, 9 p, 14 q, 16 q, 17 p, 18 q, 21 q$, and $Y$, and gains were seen on 1q, 3q, $5 p, 6 p, 7 p q, 8 q, 12 q, 13 q, 15 q, 17 q, 18 p, 20 q$, and Xpq [15-19]. Loss of $14 \mathrm{q} 31-\mathrm{q} 32.1$ was detected at a significantly higher frequency in Barrett's esophagus-related EAC than in gastric cardia cancers [22]. In adenocarcinomas, $\mathrm{LOH}$ detected allelic imbalance on $4 \mathrm{q}, 5 \mathrm{q}, 9 \mathrm{p}$, $13 \mathrm{q}, 16 \mathrm{q}, 17 \mathrm{p}$, and 18q suggesting the involvement of the APC3, MCC, CDKN2A, retinoblastoma 1, TP53, and DCC genes [22-24]. Moreover mutations were detected in TP53 and APC [25]. No mutations were found in DPC4, making the involvement of DPC4 unlikely [22]. Protein expression studies have attempted to determine whether EAC of Barrett's esophagus has elevated expression of ERBB2 and EGFR which are oncogenes, nevertheless these oncogenes were elevated in only a few cases with dysplasia [25,26]. In metaplastic tissue SRC oncogene and histidine triad elevated. Polyploidy and aneuploidy are two other early events in Barrett's esophagus [27-30]. Table 1, summarizes the findings mentioned above. Candidate region analysis, lowresolution conventional comparative genomic hybridization, and low-density single nucleotide polymorphism arrays have identified many of the chromosomal aberrations involved in the progression from Barrett's esophagus to EAC.

Several well-known tumor suppressor genes and oncogenes have been implicated, including p16, p53, p21, APC, Rb, SMAD4, Myc, K-ras, EGFR, cyclins, and CDKs. However, except for the deletion of 9p21 across different histologic stages and the $\mathrm{LOH}$ of p53 at later stages, the results for other chromosomal aberrations are highly heterogeneous in terms of stage, frequency, and size.

\section{Conclusion}

Currently no specific biological or genetic marker is available for predicting the progression of Barrett's esophagus to EAC although we know that most cases of EAC start as Barrett's esophagus. Although many linkages have been hypothesized, further studies are needed to determine more genetic correlation.

\section{References}

1. Haggitt RC (1994) Barrett's esophagus, dysplasia, and adenocarcinoma. Hum Pathol 25: 982-993. [Crossref]

2. Cameron AJ, Lomboy CT (1992) Barrett's esophagus: age, prevalence, and extent of columnar epithelium. Gastroenterology 103: 1241-1245.[Crossref]

3. Dixon J, Strugala V, Griffin SM, Welfare MR, Dettmar PW, et al. (2001) Esophageal mucin: an adherent mucus gel barrier is absent in the normal esophagus but present in columnar-lined Barrett's esophagus. Am J Gastroenterol 96: 2575-2583. [Crossref]

4. Jovov B, Van Itallie CM, Shaheen NJ, Carson JL, Gambling TM, et al. (2007) Claudin-18: a dominant tight junction protein in Barrett's esophagus and likely contributor to its acid resistance. Am J Physiol Gastrointest Liver Physiol 293: G11061113. [Crossref]

5. Tobey NA, Argote CM, Vanegas XC, Barlow W, Orlando RC (2007) Electrical parameters and ion species for active transport in human esophageal stratified squamous epithelium and Barrett's specialized columnar epithelium. Am J Physiol Gastrointest Liver Physiol 293: G264-70. [Crossref]

6. Barrett MT, Sanchez CA, Prevo LJ, Wong DJ, Galipeau PC, et al. (1999) Evolution of neoplastic cell lineages in Barrett oesophagus. Nat Genet 22: 106-109. [Crossref]

7. Maley CC, Galipeau PC, Finley JC, Wongsurawat VJ, Li X, et al. (2006) Genetic clonal diversity predicts progression to esophageal adenocarcinoma. Nat Genet 38: 468-473. [Crossref]

8. Blot WJ, Devesa SS, Kneller RW, Fraumeni JF Jr (1991) Rising incidence of adenocarcinoma of the esophagus and gastric cardia. JAMA 265: 1287-1289. [Crossref]

9. Wijnhoven BP, Siersema PD, Hop WC, van Dekken H, Tilanus HW (1999) Adenocarcinomas of the distal oesophagus and gastric cardia are one clinical entity Rotterdam Oesophageal Tumour Study Group. Br J Surg 86: 529-535. [Crossref]

10. Farrow DC, Vaughan TL (1996) Determinants of survival following the diagnosis of esophageal adenocarcinoma (United States). Cancer Causes Control 7: 322-327. [Crossref]

11. Office for National Statistics (ONS) (2011) Cancer survival in England: Patients diagnosed 2005-2009 and followed up to 2010. London: ONS.

12. Wong DJ, Paulson TG, Prevo LJ, Galipeau PC, Longton G, et al. (2001) p16(INK4a) lesions are common, early abnormalities that undergo clonal expansion in Barrett's metaplastic epithelium. Cancer Res 61: 8284-8289. [Crossref]

13. Eads CA, Lord RV, Wickramasinghe K, Long TI, Kurumboor SK, et al. (2001) Epigenetic patterns in the progression of esophageal adenocarcinoma. Cancer Res 61: 3410-3418. [Crossref]

14. Maley CC, Galipeau PC, Li X, Sanchez CA, Paulson TG, et al. (2004) Selectively advantageous mutations and hitchhikers in neoplasms: p16 lesions are selected in Barrett's esophagus. Cancer Res 64: 3414-3427. [Crossref]

15. Li X, Galipeau PC, Sanchez CA, Blount PL, Maley CC, et al. (2008) Single nucleotide polymorphism-based genome-wide chromosome copy change, loss of heterozygosity, and aneuploidy in Barrett's esophagus neoplastic progression. Cancer Prev Res (Phila) 1: 413-423. [Crossref]

16. Menke-Pluymers MB1, van Drunen E, Vissers KJ, Mulder AH, Tilanus HW, et al (1996) Cytogenetic analysis of Barrett's mucosa and adenocarcinoma of the distal esophagus and cardia. Cancer Genet Cytogenet 90: 109-117. [Crossref]

17. Riegman PH, Vissers KJ, Alers JC, Geelen E, Hop WC, et al. (2001) Genomic alterations in malignant transformation of Barrett's esophagus. Cancer Res 61: 31643170. [Crossref]

18. Huang Y, Boynton RF, Blount PL, Silverstein RJ, Yin J, et al. (1992) Loss of heterozygosity involves multiple tumor suppressor genes in human esophageal cancers. Cancer Res 52: 6525-6530. [Crossref]

19. Tarmin L, Yin J, Zhou X, Suzuki H, Jiang HY, et al. (1994) Frequent loss of heterozygosity on chromosome 9 in adenocarcinoma and squamous cell carcinoma of the esophagus. Cancer Res 54: 6094-6096. [Crossref]

20. González MV, Artímez ML, Rodrigo L, López-Larrea C, Menéndez MJ, et al. (1997) Mutation analysis of the p53, APC, and p16 genes in the Barrett's oesophagus, dysplasia, and adenocarcinoma. J Clin Pathol 50: 212-217. [Crossref]

21. al-Kasspooles M, Moore JH, Orringer MB, Beer DG (1993) Amplification and overexpression of the EGFR and erbB-2 genes in human esophageal adenocarcinomas. Int J Cancer 54: 213-219. [Crossref] 
22. Filipe MI, Jankowski J (1993) Growth factors and oncogenes in Barrett's oesophagus and gastric metaplasia. Endoscopy 25: 637-641. [Crossref]

23. Kumble S, Omary MB, Cartwright CA, Triadafilopoulos G (1997) Src activation in malignant and premalignant epithelia of Barrett's esophagus. Gastroenterology 112 348-356. [Crossref]

24. Michael D, Beer DG, Wilke CW, Miller DE, Glover TW (1997) Frequent deletions of FHIT and FRA3B in Barrett's metaplasia and esophageal adenocarcinomas. Oncogene 15: 1653-1659. [Crossref]

25. Galipeau PC, Cowan DS, Sanchez CA, Barrett MT, Emond MJ, et al. (1996) 17p (p53) allelic losses, 4N (G2/tetraploid) populations, and progression to aneuploidy in Barrett's esophagus. Proc Natl Acad Sci USA 93: 7081-7084. [Crossref]
26. Garcia M, Jemal A, Ward EM, et al. (2007) Global cancer facts \& figures. Atlanta (GA): American Cancer Society.

27. Jemal A, Siegel R, Ward E, Hao Y, Xu J, et al. (2009) Cancer statistics, 2009. $C A$ Cancer J Clin 59: 225-249. [Crossref]

28. Horner MJ, Ries LAG, Krapcho M, et al. (2009) SEER cancer statistics review, 1975 2006. Bethesda (MD): National Cancer Institute.

29. Jian Gu, Jaffer A. Ajani, Ernest T. Hawk, et al (2010) High-Density Single Nucleotide Polymorphism Array Analysis Barrett's Esophagus and Esophageal Adenocarcinoma: A Genome-Wide Catalogue of Chromosomal Aberrations in. Cancer Prev Res 3: 11761186.

30. British Society of Gastroenterology Guidelines for the diagnosis and management of Barrett's columnar-lined oesophagus (2005). A Report of the Working Party of the British Society of Gastroenterology.

Copyright: (C2015 Karkout KA. This is an open-access article distributed under the terms of the Creative Commons Attribution License, which permits unrestricted use, distribution, and reproduction in any medium, provided the original author and source are credited. 